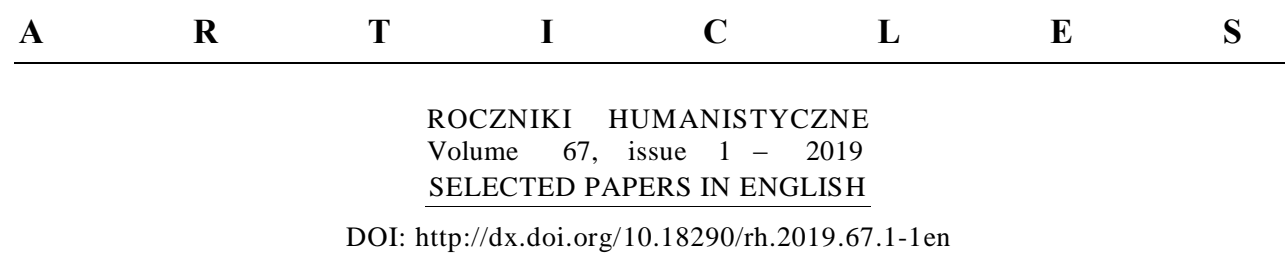

TOMASZ GARBOL

\title{
EPIPHANIES OF THE EXILES: EXILE FROM THE HERITAGE OF TRADITION
}

The meaning of the term epiphany, ${ }^{1}$ one that is a model for the modernistic formation and that still functions in the study of literature, is derived from James Joyce's two works - A Portrait of the Artist as a Young Man and the unfinished Stephen Hero $^{2}$. In the latter novel, its protagonist Stephen Daedalus, during a walk, discovers the meaning of an accidentally heard conversation between a man and a woman flirting with each other. Snatches of the conversation-Stephen only heard from the man's mouth a repeated "I," and from the woman's: "O, yes... I was... at the... cha... pel..." and "O... but you're... ve...ry wick... ed..."3_made such a strong impression on him that they induced an esthetic reflection:

Dr. hab. TOMASZ GARBOL - The John Paul II Catholic University of Lublin, Faculty of Humanities, Center for Research on Religious Literature; Associate Professor; e-mail: tomeus@kul.lublin.pl

The Polish version of the article was published in Roczniki Humanistyczne vol. 61, issue 2 (2014).

${ }^{1}$ As a starting point I accept the conception of a work of art as an epiphany as used by literature experts - see Ryszard NyCZ, Literatura jako trop rzeczywistości. Poetyka epifanii w nowoczesnej literaturze polskiej (Literature as a Track of Reality. Poetics of Epiphany in Modern Polish Literature) (Kraków: Towarzystwo Autorów i Wydawnictw Prac Naukowych Universitas, 2001), 45-49. In addition, there may be bibliographical information concerning the interpretation of the issue of epiphany by Charles Taylor-an interpretation constituting the starting point in Nycz's deliberations.

${ }^{2}$ According to Umberto Eco (The Aesthetics of Chaosmos: The Middle Ages of James Joyce (Harvard University Press 1989), 48) Gabriele d'Annunzio's novel The Flame of Life. A Novel was an inspiration for Joyce. Joyce knew it and appreciated it; its first part bears the title Epiphany of Fire, and all of Stelio Effrena's esthetic ecstasies are described in it as epiphanies of beauty, Eco reminds us.

${ }^{3}$ James JoycE, Stephen Hero, ed. by Theodore Spencer (New York: New Directions Books, 1955), 211. 
This triviality made him think of collecting many such moments together in a book of epiphanies. By an epiphany he meant a sudden spiritual manifestation, whether in the vulgarity of speech or of gesture or in a memorable phase of the mind itself. He believed that it was for the man of letters to record these epiphanies with extreme care, seeing that they themselves are the most delicate and evanescent of moments ${ }^{4}$.

This discovery forms Stephen's ultimate choice of his artistic way. The scene of a meeting on a beach where a long, shallow river flows is an important event preparing him for this decision:

A girl stood before him in midstream, alone and still, gazing out to sea. She seemed like one whom magic had changed into the likeness of a strange and beautiful seabird. [...]

- Heavenly God! cried Stephen's soul, in an outburst of profane joy. He turned away from her suddenly and set off across the strand. His cheeks were aflame; his body was aglow; his limbs were trembling. On and on and on and on he strode, far out over the sands, singing wildly to the sea, crying to greet the advent of the life that had cried to him. [...] To live, to err, to fall, to triumph, to recreate life out of life! A wild angel had appeared to him, the angel of mortal youth and beauty, an envoy from the fair courts of life, to throw open before him in an instant of ecstasy the gates of all the ways of error and glory. ${ }^{5}$

Stephen's stroll in the riverbed becomes a portent of his way of life oriented to art. In the "on," repeated four times and additionally strengthened with the adverb "far," the spatialization of the intellectual attitude happens to move away from the tradition that was cultivated in the protagonist's family and in the Irish Catholic society whose aims and aspirations he came to know - and initially considered his own - as a student of a Jesuit college. The occurance on the beach - in the narrative order - is a consequence of his resignation from his plans to join the Society of Jesus. Stephen sets out for a walk that proves to be formative for him, having discovered just a little earlier, when passing the Jesuit house at Gardiner Street, that his earlier vocational appeal "had already fallen into an idle formal tale," 6 that "He was destined to learn his own wisdom apart from others or to learn the wisdom of others himself wandering among the snares of the world." ${ }^{7}$ Having made the decision about resigning from becoming a priest, Stephen drops into his

\footnotetext{
${ }^{4}$ Ibid.

${ }^{5}$ James Joyce, A Portrait of the Artist as a Young Man and Dubliners, with an introduction and notes by Kevin J.H. Dettmar (New York: Barnes \& Noble Classics, 1982), 150.

${ }^{6}$ Ibid., 141.

${ }^{7}$ Ibid.
} 
home from which his parents are absent as they have gone to look for a new place for their family to live in. It is another change of the Daedaluses' home, due to their poor financial condition. On the plane of symbolic meanings this fact, however, is part of the reason why this situation is also one of parting with someone who is also searching for some roots. Although Stephen's mother declares her deep faith, her helplessness in the face of her son's doubts proves that she is lost in a changing world. Breaking the ties uniting him with his family and with the university, Daedalus breaks free from the limitations of boyhood - first the narrator states: "So he had passed beyond the challenge of the sentries who had stood as guardians of his boyhood"8; and then a question full of relief is asked: "Where was his boyhood now?"

The protagonist of the story embarks on a path of exile. Not only in the literal meaning, revealed in the finale of the story in the form of the decision about his plan to leave Dublin he tells his friend about, but also in a cultural and spiritual sense. Stephen gives up the tradition in which his personality was formed. He sentences himself to exile, to exile and not to liberation. ${ }^{10}$ The ties with the tradition remain, but its elements are reinterpreted. The mechanism of this attitude is revealed when one notices the different meanings of the two different usages of a certain comparison. In the first one, it is the statue of the Blessed Virgin that is compared to a bird noticed on the way to the beach:

He crossed the bridge over the stream of the Tolka and turned his eyes coldly for an instant towards the faded blue shrine of the Blessed Virgin which stood fowlwise on a pole in the middle of a ham-shaped encampment of poor cottages $[\ldots] .{ }^{11}$

Soon after this the girl on the beach appears to him as a bird - this time a strange, beautiful seabird:

Her long slender bare legs were delicate as a crane's and pure save where an emerald trail of seaweed had fashioned itself as a sign upon the flesh. Her thighs, fuller and soft-hued as ivory, were bared almost to the hips, where the white

\footnotetext{
${ }^{8}$ Ibid., 144.

${ }^{9}$ Ibid., 150.

${ }^{10}$ His spirit is characterized by a state of tension that the emigrant, as portrayed by Cioran, lacks. The Romanian philosopher remarks that an emigrant is threatened with wasting the emotions accompanying the nostalgia for what is lost. See: Emil M. Cioran, Advantages of Exile, in The Temptation to Exist, translated from the French by Richard Howard, introduction by Susan Sontag (Chicago: Quadrangle. Books, 1968), 77-78.

${ }^{11}$ JoYCE, A Portrait of the Artist as a Young Man, 141.
} 
fringes of her drawers were like feathering of soft white down. Her slate-blue skirts were kilted boldly about her waist and dovetailed behind her. Her bosom was as a bird's, soft and slight, slight and soft as the breast of some dark-plumaged dove. But her long fair hair was girlish: and girlish, and touched with the wonder of mortal beauty, her face. ${ }^{12}$

The conclusion of this description of the young man's fascination with the sensual good looks of the girl reveals an important meaning of the affirmed beauty, namely, mortality. The charm is devoid of the supernatural aspect that Stephen wants to reject, giving up the attitude of faith. At the same time, however, his experience is realized inside the model shaped by the Christian tradition. This is proven by the religious motifs of the angel, envoy, Heavenly God, and those that are used to emphasize the conviction that in the protagonist's imagination the girl takes the place of the Blessed Virgin. If the Mother of God incarnates the immortal beauty of Divine Wisdom, then the girl on the beach becomes the sign of human, mortal beauty for Stephen. The meaning of her figure appears to Stephen clearly as part of the model of the Catholic Marian tradition, surely well known to him, as a talented alumnus of a Jesuit school, coming from a Catholic family; the girl is here a dove, she appears in an aura of miraculousness, arouses in Stephen a need to worship her, and finally she becomes his guide. After all, it is she who sends him going:

\begin{abstract}
She was alone and still, gazing out to sea; and when she felt his presence and the worship of his eyes her eyes turned to him in quiet sufferance of his gaze, without shame or wantonness. Long, long she suffered his gaze and then quietly withdrew her eyes from his and bent them towards the stream, gently stirring the water with her foot hither and thither. ${ }^{13}$
\end{abstract}

First, with a subtle delicacy, the unknown girl stops the hypnotic meeting of their looks, and then, stirring the water with her foot, she as it were strengthens the current that will lead Stephen "on" towards a new life. If the Blessed Virgin is a mother in the face of whom a man feels like a child who wants to be taken into her arms, as happens with the inhabitants of the cottages surrounding the shrine, the girl is a woman who awakens the man in Stephen with her sensual appearance and gestures that, in a way, are erotic and, at the same time, she does not keep him with her but sends him going on his way.

\footnotetext{
${ }^{12}$ Ibid., 150.

${ }^{13}$ Ibid., 150.
} 
Stephen chooses the role of an exile from the tradition that has formed him. If he were a reckless refugee he would blaze new trails through the wilderness. However, he is an exile longing for what he has left behind, and to what there is no return. He follows the way charted by Catholic tradition. But, recognizing it as dead, he fills the general outline of the model coming from it with new contents. This novelty is well expressed by Daedalus' confession:

I will not serve that in which I no longer believe, whether it call itself my home, my fatherland, or my church: and I will try to express myself in some mode of life or art as freely as I can and as wholly as I can, using for my defence the only arms I allow myself to use-silence, exile, and cunning. [...].

And I am not afraid to make a mistake, even a great mistake, a lifelong mistake, and perhaps as long as eternity too. ${ }^{14}$

Stephen is an exile from the heritage of the tradition he does not want to serve, intending to subordinate it to his aims, to change it into a tool of his artistic activities. The presentation of the epiphany-by means of Aquinas' notions and his model of thinking - defines more closely the way of using the tradition from which he feels an exile. It consists in reducing it, in extracting from it only what concerns its very existence, its beauty and sublimity, that are independent from cultural and religious contexts. ${ }^{15}$

\section{REDUCTION}

The model of epiphany coming from Joyce's works - that of an experience to which emotions, thoughts and intellectual attitudes co-forming an exile are also joined-gains an additional aspect in Polish literature connected with historical events. What is meant here is the meaning of exile that is revealed owing to the extreme experiences that the participants and witnesses of World War II had-it is the intellectual and artistic attitudes that may be shaped in the circumstances of war. ${ }^{16}$

\footnotetext{
${ }^{14}$ Ibid., 219.

15 "It is almost impossible to reconcile all tradition whereas it is by no means impossible to find the justification of every form of beauty which has ever been adored on the earth by an examination into the mechanism of esthetic apprehension [...]" (JOYCE, Stephen Hero, 212).

${ }^{16}$ This does not change the fact which Włodzimierz Bolecki pointed to ("Kilka uwag o periodyzacji literatury polskiej" [A few remarks on the periodization of Polish literature], in IDEM, Modalności modernizmu. Studia. Analizy. Interpretacje [Modalities of Modernism. Studies. Analyses.
} 
One literary image that can serve as an introduction to this issue is the scene of life in occupied Poland in Czesław Miłosz's The Captive Mind:

\begin{abstract}
A man is lying under machine-gun fire on a street in an embattled city. He looks at the pavement and sees a very amusing sight: the cobblestones are standing upright like the quills of a porcupine. The bullets hitting against their edges displace and tilt them. Such moments in the consciousness of a man judge all poets and philosophers. [...] The vision of the cobblestones is unquestionably real, and poetry based on an equally naked experience could survive triumphantly that judgment day of man's illusions. ${ }^{17}$
\end{abstract}

This is a fragment of the essayist's reflection on the issue of war as an intellectual and artistic ordeal for people and for the products of their thought. He who once found himself in the situation of a man lying on a street raked with machine-gun fire gains a new perspective on viewing reality. Miłosz himself defines it as the "elimination of emotional luxuries," 18 reconstructing the specific character of an "Eastern intellectual"-afflicted with war and tempted by the Soviet "New Faith." This "elimination of emotional luxuries," however, has not only a political, but also an artistic, meaning. Watching cobblestones in such circumstances may become an epiphany in the meaning given to this term by Joyce. The "elimination" that Miłosz speaks about turns out to be the purification of perception, so that the phenomenon of existence is correctly recognized. This becomes clear in the context of the confession concluding Miłosz's autobiographical essay The Border of Peace. The poet concludes his description of a daring escapade from Lithuania, occupied by the Soviets, to Warsaw, occupied by the Germans, with the reflection:

An unsuspected shape of existence could almost be discerned: an existence from which the superfluous, including the future, was removed, and yet, for all that,

\footnotetext{
Interpretations] (Warsaw: Instytut Badań Literackich PAN: Fundacja Akademia Humanistyczna, 2012), 40), reminding us that from the point of view of the historical-literary process, the literature of war emigration - over time becoming a post-war emigration - "is a natural (personal, institutional, esthetic, axiological and ideological) continuation of interwar literature." The validity of basing the periodization of contemporary Polish literature on border dates, the dates of turning points, is also challenged by Jerzy Święch (Czy czeka nas nowa periodyzacja literatury wspótczesnej? [Are we going to see a new periodization of contemporary literature]) in IDEM, Nowoczesność. Szkice o literaturze polskiej XX wieku (Modernity. Sketches about Polish Literature of the $20^{\text {th }}$ Century) (Warsaw: Wydawnictwo Naukowe PWN, 2007), 39.

${ }^{17}$ Czesław MiŁosz, The Captive Mind, trans. by Jane Zielonko (New York: Secker \& Warburg, 1955), 39.

${ }^{18}$ Ibid.
} 
was no worse. And this descent, if we apply the measuring rod of social prestige, to the level of black slaves in colonial countries had put the highest form of liberty within my reach. ${ }^{19}$

What is meant here is an experience like that which became the existential content of the reflection formulated in Captive Mind. In both records it is a situation in which the immediate threat to one's life sharpens and purifies the perception of the world. This is the meaning of the confession-preceding the conclusion of an essay in Native Realm - made by the man who remembers his escape through pine wood, from tree to tree, between the shots fired by military policemen aimed at him from all directions: "As I crawled on all fours on the pine needles, I enlarged in my disinterested imagination a drawing of a twig or an ant carrying its load [...]." ${ }^{20}$ The essay's title "The Peace Boundary" has a metaphorical, and not only topographical, meaning - it is a border of experiences, in which a man gets rid of his own life, becomes indifferent to pain and fear, and sensitive to his very existence. The point here is a man's inner peace-favoring creativity - when he has become indifferent to the permanent threat to existence.

The aspect of exile revealed by Miłosz-one that is absent from Joyce's reflection-is its historicity. Not only in the meaning that exile is more and more often a man's fate in the great history of political and social transformations, but also because individual human history is the history of exile:

\begin{abstract}
We can easily imagine an old emigrant who, meditating about the country of his youth, realizes that it is not only the number of kilometers that separates him from it, but it is also the wrinkles on his face and his grey hair, the traces left by the severe guardian of borders, the time. ${ }^{21}$

[...] the archetypal expulsion from the Garden of Eden is repeated in our lives independent of the question if this garden is the mother's womb or the wonderful trees of our childhood. ${ }^{22}$
\end{abstract}

The existential aspect of the historicity of human life that is revealed in one's experience is interpreted by Miłosz as an echo of the expulsion from the Garden of Eden. The fate of an emigrant-or the lack of a home that is

\footnotetext{
${ }^{19}$ Czesław Mıьosz, Native Realm. A Search for Self-Definition, trans. from the Polish by Catherine S. Leach (Berkeley: University of California Press, 1981), 228.

${ }^{20}$ Ibid.

${ }^{21}$ Czesław MıŁosz, "O wygnaniu” (On Exile), in Szukanie ojczyzny (In Search of a Homeland) (Kraków: Znak, 2001), 214.

${ }^{22}$ Ibid., 213.
} 
analogical to it - strengthens this universal experience. It is not accidental that Miłosz refers to the biblical version of the archetype, since the religious aspect of the expulsion is particularly important for him. Firstly, because the poet perceives the power of the biblical story as accurately interpreting the dark side of human existence. ${ }^{23}$ Secondly, a loss of the possibility to follow religious observances, making a believer an exile, cleanses religion of its cultural habits, simplifications and stereotypizations. This happens in the meaning to which Miłosz pointed in Captive Mind: "Perhaps some pressure is needed if Christianity is to be reborn. The religious fervor of the Christians in the people's democracies would seem to indicate as much." ${ }^{24}$ Taking into consideration his critical appraisal of experiencing religion-transformed into a custom, a kind of folklore-in the prosperous Western countries, he should be recognized as a descendant of Joyce's. This is because Miłosz also notices that the model of experiencing religion that was common up till now, as well as - speaking more broadly - of participating in culture, has been exhausted. At the same time, he experiences war damage not as an end, but as a beginning initiated by the cleansing: "[...] what appeared to be the end was not the end of either tradition or literature or art." 25

Świat. Poema naiwne. (The World. Nä̈ve Poems), published under the author's own imprint in $1943,{ }^{26}$ is a literary testimony to the purification of the emotions and thoughts during the war whose catastrophic dimension the poet clearly saw. ${ }^{27}$ The return of his imagination to the country of his childhood is ambiguous in at least two aspects. Firstly, it is not simply hiding from the horror of the war in safe forms and reassuring memories. Secondly, we are not dealing with an unambiguous ridiculing of the naivety of a return to the truths that are constantly negated in the streets of German-occupied Warsaw, where the poem was written. The movement of the imagination that is going on here may be described as an impossible return-undertaken with the utter consciousness of its impossibility and, at the same time, with an overwhelming conviction of the necessity of taking this step backwards. The World allows us to look into an exile's experience. On the one hand, he sees

\footnotetext{
${ }^{23}$ See: "Rozmowa dwudziesta czwarta. O Upadku" (The twenty-fourth conversation. On The Fall), in Czesław MıŁosz, Podróżny świata. Rozmowy z Renata Gorczyńska (A Traveller of the World. Conversations with Renata Gorczyńska) (Kraków: Wydawnictwo Literackie, 2002), 296-302.

${ }^{24}$ Captive Mind, 41.

${ }^{25}$ Native Realm, 247.

${ }^{26}$ Świat. Poema naiwne (The World. Nä̈ve Poems), a reprint of the original edition, ed. Pawer Kądziela (Warsaw: Więzi, 2011).

${ }^{27}$ See e.g. Czesław MiŁosz, "Intermezzo," in Native Realm, 253-257.
} 
his status of a disinherited one, and on the other he takes up the challenge that is the chance to be purified owing to his passing through a trauma.

The insights into the reality in the poems constituting the whole of The World are made by a man who has discovered the phenomenon of existence, lying on the street whose cobblestones are standing upright like the quills of a porcupine under machine-gun fire, or who admired a pine twig clinging to the forest floor during a break in the shooting of German guns. The epiphanic poetical records of the phenomenon of existence arise here from the depth of the experience of exile, intensified by the experience of war. The clarity of the perception of the world-for example, in the poem The Wicket Gate-does not come from the poet's primary, innocent, naïve fascination with the world, but from the need to find a perspective that would allow him to cope with the catastrophe of war without escaping it. "The pickets are painted white at the top. / White and sharp, like tiny flames. I Strange that this never bothered the birds. / [...] // The handle is of wood worn smooth over time, / Polished by the touch of many hands. / Nettles like to steal under the handle / [...]"28 - the tone of cheerful clarity of the poetic description again and again breaks down to give way to the non-intrusive associations of thought flowing with an ever darker current of the reckoning of issues that are difficult and painful. Is not the meaning of the comparison of white fence boards' sharp tops to flames and of the not-quite-certain bewilderment - from the perspective of children growing up in a green valley, who know birds' habits - aused by the fact that birds do not mind it? Does not the nettle "creeping" towards the smooth knob appear here as a sign of pain and being hurt? I do not claim that "the fence boards like flames" are a reflection of the images of the war horror, for example, being arranged into "a row of burning blades" 29 . The whole poem, however, has in it the tension of a reflection de profundis on the experience of a mature man, fully conscious of the dark truth about the world, and searching for a light in the depths of this truth - and maybe even at its bottom. This aspect-a postulatory one-of the poem was described by Jacek Lukasiewicz: "The World -is not the world as it is, but as it should be. It is a space of a postulated approval." ${ }^{30}$

\footnotetext{
${ }^{28}$ Czeslaw Milosz, New and Collected Poems 1931-2001 (New York: Ecco, 2001), 37.

${ }^{29}$ Michał KŁosińsKi, "Miejsca traumy w Świecie Miłosza" (The spots of trauma in The World by Czesław Miłosz), Postscriptum Polonistyczne 1 (2011): 141.

30 "Przestrzeń 'świata naiwnego.' O poemacie Czesława Miłosza 'Świat"” ("The space of the 'Naive World.' About Czesław Miłosz's 'The World',”) in Poznawanie Miłosza 2, cz. 1 (Getting to Know Mitosz 2, part 1), ed. Aleksander Fiut (Kraków: Wydawnictwo Literackie, 2000), 145.
} 
In the poem "Królestwo ptaków" (The Bird Kingdom) this trend of thinking about the world showing its heights and abysses assumes a sharpened shape: "What is the earth for them? A lake of darkness. / It has been swallowed by the night forever. / They, above the dark as above black waves, / Have their homes and islands, saved by the light. // If they groom their long feathers with their beaks / And drop one of them, it floats a long time / Before it reaches the bottom of the lake / And brushes someone's face, bringing news / From a world that is bright, beautifulm warm, and free." Only sometimes does a single sign from the heights of lightness penetrate into the abyss of darkness. It would be difficult to accept this vision as representative for the whole poem, but it determines the scale of the pain of exile. The radiance of the green valley seen from the perspective of an innocent child is, in turn, the measure of the epiphanic claritas.

The emotional self-restraint declared by Miłosz is an attitude of which the patron is Balzac, the meaning of which the poet pointed to in a conversation concerning A Treatise on Morality: "Joseph Conrad, read at that time, sounded too pompous, too romantic. Especially in Aniela Zagórska's translations, where it is a lot more romantic than in the original version. On the other hand, Balzac-because he was so meaty, so material-perfectly well withstands the confrontation with the brutalized reality of the occupation. Conrad-not very well." 32 This confession reveals the motivation of the poetical choice of the concretum. The "elimination of emotional luxuries" in Miłosz's poetry means giving up abstractions, in which great ideas might be formulated (for instance - or even primarily - the idea of patriotism), in favor of concrete things, in which the phenomenon of existence is revealed.

\section{THE LOSS}

Exile is not only a purification, but also a loss. Zbigniew Herbert's poetry is a significant testimony - and surely not only from a Polish perspective ${ }^{33}-$

\footnotetext{
${ }^{31}$ MiLosz, New and Collected Poems, 52, 204.

32 "Pokochać sprzeczność. Z Czesławem Miłoszem rozmawiają Aleksander Fiut i Andrzej Franaszek" (To love the contradiction. Aleksander Fiut and Andrzej Franaszek talk to Czesław Miłosz), in Czesław Mıosz, Rozmowy polskie 1979-1998 (Polish Conversations 1979-1998) (Kraków: Wydawnictwo Literackie, 2006), 576.

${ }^{33}$ See Seamus Heaney's poem "The Hiperborean" (in Stanisław Barańczak's translation "Hiperbojerczyk", in Poznawanie Herberta 2, selected and supplied with an introduction by Andrzej Franaszek (Kraków: Wydawnictwo Literackie, 2000), 52), written after Herbert's death-he was defined there as a "herald" of Apollo who was in exile.
} 
to this artistic truth, whose intuition may be found in Joyce. Its readers have perceived in it for a long time the overwhelming feeling of loss of the Judaeo-Christian culture, the experience of being expelled from Arcadia ${ }^{34}$. Acute poetic observations - as in the poem Jonah, in which Herbert talks about a contemporary unfulfilled prophet-deserter: "the parable / applied to his head / expires / and the balm of the legend / does not take to his flesh"35 or as in the poetic prose exposing the "The Missing Knot" degrading culture: "Electra works for a cooperative. Orestes is a pharmacology student. He will soon marry his reckless girlfriend with a pale skin and eternally tear-filled eyes" contemporary culture that, depraved of the hierarchy of fundamental values defining the dignity of human existence, becomes - often - a small broken soul / with a great self-pity ${ }^{37}$ over its own meanness.

The same loss, however, in Herbert's poetry also has an important epiphanic aspect, as in the late poem "Strefa liryczna" (Lyrical Zone):

A view of a park and a wall in the early evening light / as in Corot-lemon peel skin of a powdered cheek after a ball / air cast in gold and you don't hear anything here no whispers / or stifled cries no touch sweaty hands clatter of hooves / only the soul becomes a painfully fragile spiderweb / and it hangs in the air like the Gioconda's smile / the smile of Etruscan girls // the Sphinx's smile. ${ }^{38}$

The lyrical zone is, at the same time, the zone of the experience of exile-absolutely literal, albeit not obviously, and indirectly revealed in one of the poet's memories of Lviv:

My fundamental experience of painting was, however, certainly the view from the window of the tenement house I lived in in Lvov, the view of a wall that was most beautiful when the sun was setting. And the color, that unimaginable color haunts me. It was an abstract experience. That wall with a warm light. [...] And here some problem of the inexpressible character of the world started for me. I knew

\footnotetext{
${ }^{34}$ See Stanisław BARAŃCZAK, Uciekinier z Utopii. O poezji Zbigniewa Herberta (A Fugitive from Utopia. About Zbigniew Herbert's Poetry) (Cambridge, Mass.: Harvard University Press, 1987), also see here a discussion of the first analyses of Herbert's poetry situating it in the current of revived Classicism.

${ }^{35}$ Zbigniew Herbert, The Collected Poems 1956-1998, translated and Edited by Alissa Valles. With Additional Translations by Czeslaw Milosz and Peter Dale Scott. Introduction by Adam Zagajewski (New York: Ecco 2007), 183.

${ }^{36}$ Ibid., 256

${ }^{37}$ See Zbigniew Herbert, “Dlaczego klasycy” (Why Classics), ibid., 267.

${ }^{38}$ Ibid., 545.
} 
that the wall was most beautiful only for a few minutes - in the sun. Usually unattractive, grayish — in the sun it acquired the color of hot ocher. ${ }^{39}$

The validity of the association of the two records is additionally confirmed by Barbara Toruńczyk's remark, perceiving in the poem a record of the experience of the poet who lived the final years of his life in a flat in Warsaw:

Now I think that maybe it was the description of the view that stretched beyond his window when he did not get up from his bed and only with difficulty raised his body on the sore elbow to sketch the façade of San Marco in his notebook. ${ }^{40}$

Having compared these communications one may risk the thesis that The Lyrical Zone is a record of an elegiac rapture at the lost view from the window of the Lvov tenement house, for a moment revived in the Warsaw flat. This epiphany is strengthened by the artistic energy coming from the experience of a loss. From the perspective of the mechanism of perception this happens because a short visual impression - the color of the wall lit by the sun's rays-owes its intensity to its uniqueness and the ability to disappear, as well as to the on-looker's awareness that the view could plunge into shadow or darkness in a moment. From the perspective of the subject's thought, a loss is a state-of existence, of the intellect, of the spirit-preparing for an epiphany. The unusual sensation caused by the sight of the color of the wall is here poetically described as becoming calm, as stopping, as a lack. One may guess, as Toruńczyk did, that in the poem we get a record of the stifling of the activity of an ill body. The loss affects, however, first of all the soul-it delimits the range of the "lyrical zone". "[...T]he soul becomes a painfully frail cobweb" - this hidden poetic image evokes a state of limbo, the feeling of one's own non-coherence, of existence as frail as a cobweb, of being marked with irremovable pain. ${ }^{41}$

\footnotetext{
39 “Światło na murze. Dwadzieścia lat temu ze Zbigniewem Herbertem rozmawiał Marek Sołtysik" (A Light on the wall. Twenty years ago Marek Sołtysik talked to Zbigniew Herbert). PlusMinus 2001 no. 30 [a supplement to "Rzeczpospolita" of July 28-29, 2001], 1.

${ }^{40}$ Barbara TORUŃCZYK, "Dukt pisania, dukt pamięci" (The track of writing, the track of memory), in Poznawanie Herberta 2, 80.

${ }^{41}$ Being marked with the pain of the poetically-described state of staying in the lyrical zone rather excludes locating it in the eschatological dimension. Cf. Krystyna PIETRYCH, "W strefie lirycznej. O kilku wierszach z Epilogu burzy" ("In the lyric zone. About a few poems from Epilogue to a Storm”), in: Twórczość Zbigniewa Herberta. Studia (Zbigniew Herbert's Works. Studies), ed. Marzena Woźniak-Łabieniec, Jerzy Wiśniewski (Kraków: Uniwersitas, 2001), 312.
} 
Owing to the comparisons built of motifs coming from La Gioconda, Etruscan art and the Sphinx, loss also becomes a question of cultural references. The condition of the soul - the lyrical zone-also includes participation in culture. La Gioconda, Etruscan girls and the Sphinx - as mysterious, uncertain, similar to a frail cobweb as is the state of the soul-are included in the experience of loss. Their absence is similarly overwhelming and discernible. On the one hand, such a state of the soul-extended to culture-is fulfilled in the experience of the epiphany of the light on the wall. And on the other, the sensual quality of existence grasped in Herbert's lyric is not accessible apart from the frail "cobweb" limbo. ${ }^{42}$

The experience of loss is a factor that models the shape of the epiphany - this intuition is well shown in Herbert's drama Reconstruction of a Poet by the character of Homer who is shown as a writer suffering from the loss of sight, looking for new ways of artistic expression: "It was necessary to learn anew, starting not from Troy, not from Achilles, but from a sandal, from a buckle of a sandal, from a pebble carelessly kicked on the road." 43 The famous poem Pebble-one of Herbert's poetic identification marks - is an integral part of the drama ${ }^{44}$ : "I feel a heavy remorse / when I hold it in my hand / and its noble body / is permeated by false warmth." 45 Homer's words transferred from the drama to the volume of poetry universalize his experience of loss. The blind bard-learning the world anew, as an exile in a foreign country-is the figure of the poet. The beauty of the pebble appears false to him because it is the effect of an elusive impression. He himself feels guilty of this falseness. At the same time, touching the pebble

\footnotetext{
42 "Lyrical Zone" is a lyric insight into the attitude that Herbert defined with the words: "Understanding oneself by understanding the past, understanding the past by understanding oneself as a modus of being in the world" ("Herbert i Marquard o "duchu dziejów"'(Herbert and Marquard on 'the spirit of history'), a conversation edited and supplied with footnotes by B. Sienkiewicz, in Od tematu do tematu. Przechadzki z Balcerzanem (From a Subject to a Subject. Strolls with Balcerzan), ed. Tomasz Mizerkiewicz, Agata Stankowska (Poznań: Wydawnictwo Naukowe UAM, 2007), 340. The Polish poet specified this characterization more precisely in a conversation with the German philosopher Odo Marquard. Expressing in it his detachment from the idea of polymythical thinking, whose author was Marquard, Herbert confirms that the idea of accumulation in culture is close to him, remarking, however, that he understands it as a counterbalance to the cult of imperative progress and the power of accident. See ibid., 341.

${ }^{43}$ Zbigniew Herbert, Dramaty (Dramas), with introduction and footnotes by Jacek Kopciński, texts edited and the editor's note written by Grzegorz Wroniewicz (Warsaw: Więź, 2008), 99.

${ }^{44}$ In chronological order the poem comes from the drama. Rekonstrukcja poety (The Reconstruction of a Poet) had its first edition in Więź nos. 11-12 (1960): 91-103, and The Pebble in Tygodnik Powszechny no. 37 (1961): 5.

${ }^{45}$ Herbert, The Collected Poems, 197.
} 
allows him to experience the phenomenon of existence. Losing one sense, and with him the whole heritage of culture extolling "Troy and Achilles", opens up a new perspective.

In the reminiscence quoted Herbert speaks about discovering the inexpressible character of the world. The epiphany that is so strongly marked with reduction and loss is an experience that is a little different from the phenomenon described by Joyce. Charles Taylor finds a poetic game with the anti-epiphanic:

\begin{abstract}
an appeal beyond the present disordered age, even beyond the conflicted and twisted human to the perfection of the inanimate. [...] This negation borders on something else again, a purpose beyond stoic lucidity of vision. As with the via negativa in theology, the counter-epiphanic can be embraced not in order to deny epiphany altogether, not just in order to find a place for the human spirit to stand before the most complete emptiness, but rather to force us to the verge of epiphany. ${ }^{46}$
\end{abstract}

A new poetic quality being heard in Herbert's poem is, in the philosopher's opinion, consolidated in the historical experience of World War II:

\begin{abstract}
One of the things that came to the fore in this austere postwar poetry was a striving which had been partly latent in the earlier naturalism. It grows from the insight that to capture the most degraded or devastated reality in poetry involves a transfiguration whereby it can be confronted, and borne without flinching, by the human spirit. I argued this in Chapter: z.3 in connection with nineteenth-century realism, but it becomes more palpable with some of the stripped-down antipoetry of recent decades. Finding a language for horror and destruction can be part of a fight for spiritual survival. ${ }^{47}$
\end{abstract}

The epiphany in Polish post-war poetry owes its artistic form-innovative on a universal scale - to individual fates, to the course of the world's history and the atmosphere of the epoch being in symbiosis with historical events. Facts, choices, emotions, movements of imagination and the work of thoughts, filling various aspects of the personal and collective fate with actual contents, are joined in the experience of exile-modelling poetic epiphanies marked with emotional self-restraint and a sense of cultural loss.

\footnotetext{
${ }^{46}$ Charles TAYLOR, Sources of the Self. The Making of the Modern Identity (Cambridge, MA: Harvard University Press, 2001), 485.

${ }^{47}$ Ibid.
} 


\section{SELECTED BIBLIOGRAPHY}

BARAŃCZAK, Stanisław. Uciekinier z Utopii. O poezji Zbigniewa Herberta (A Fugitive from Utopia. About Zbigniew Herbert's Poetry). Warsaw-Wrocław: Wydawnictwo Naukowe PWN, 2001 [1 ${ }^{\text {st }}$ ed. London: Harvard University Press, 1984].

HeRBERT, Zbigniew Dramaty (Dramas), with introduction and footnotes by Jacek Kopciński, texts edited and the editor's note written by Grzegorz Wroniewicz. Warsaw: Więź, 2008.

Herbert, Zbigniew. Wiersze zebrane (Collected Poems), ed. Ryszard Krynicki. Kraków: Wydawnictwo a5, 2008.

JOYCE, James. A Portrait of the Artist as a Young Man and Dubliners, with an introduction and notes by Kevin J.H. Dettmar. New York: Barnes \& Noble Classics, 1982.

JoYCE, James. Stephen Hero, ed. by Theodore Spencer. New York: New Directions Books, 1955.

KŁosiŃSKI, Michał. "Miejsca traumy w Świecie Miłosza" (The spots of trauma in The World by Czesław Miłosz). Postscriptum Polonistyczne 1 (2011): 139-154.

MıŁosz, Czesław. Captive Mind. Trans. by Jane Zielonko. New York: Secker \& Warburg, 1955.

MiŁosz, Czesław. Native Realm. A Search for Self-Definition. Trans. from the Polish by Catherine S. Leach. Berkeley: University of California Press, 1981.

MıŁosz, Czesław. Rozmowy polskie 1979-1998 (Polish Conversations 1979-1998). Kraków: Wydawnictwo Literackie, 2006.

NYCZ, Ryszard. Literatura jako trop rzeczywistości. Poetyka epifanii w nowoczesnej literaturze polskiej (Literature as a Track of Reality. Poetics of Epiphany in Modern Polish Literature). Kraków: Towarzystwo Autorów i Wydawnictw Prac Naukowych Universitas, 2001.

ShallCross, Bożena. Zbigniew Herbert's Passage to Rapture. In Through the Poet's Eye. The Travels of Zagajewski, Herbert and Brodski, 63-84. Evanston: Northwestern University Press 2002.

TAYLOR, Charles. Sources of the Self. The Making of the Modern Identity. Cambridge, MA: Harvard University Press, 2001.

Twórczość Zbigniewa Herberta. Studia (Zbigniew Herbert's Works. Studies), ed. Marzena WoźniakŁabieniec, Jerzy Wiśniewski. Kraków: Uniwersitas, 2001.

\section{EPIPHANIES OF EXILES: EXILE FROM THE HERITAGE OF TRADITION}

\section{Summary}

The article is concerned with the function of the experience of exile that is a model for literary epiphanies. The starting point is showing the significance of this experience in James Joyce's presentation of the epiphany that is formative for modern literature. Examples from Czesław Miłosz's and Zbigniew Herbert's works are material for interpreting two important reinterpretations of the epiphany based on the experience of exile.

Key words: literature as epiphany; exile; modernism; James Joyce; Czesław Miłosz; Zbigniew Herbert.

Translated by Tadeusz Karlowicz

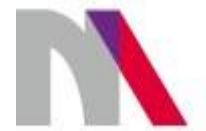

The preparation of the English version of Roczniki Humanistyczne and its publication in electronic databases was financed under contract no. 836/P-DUN/2018 from the resources of the Minister of Science and Higher Education for the popularization of science. 